\title{
LEARNING SOIL CLASSIFICATION WITH THE KAYAPÓ INDIANS
}

\author{
Miguel Cooper ${ }^{1 *}$; Edson Roberto Teramoto ${ }^{2}$; Pablo Vidal-Torrado ${ }^{1}$; Gerd Sparovek ${ }^{1}$ \\ ${ }^{1}$ USP/ESALQ - Depto. de Solos e Nutrição de Plantas, C.P. 9 - 13418-900 - Piracicaba, SP - Brasil. \\ ${ }^{2}$ Canavialis, R. James Clerk Maxwell 360 - Condomínio Techno Park - Campinas, SP - Brasil. \\ *Corresponding author <mcooper@esalq.usp.br>
}

ABSTRACT: The Kayapó Xicrin do Cateté (Xicrin) indigenous reserve is located within the Amazon forest in Pará (Brazil). The Xicrins have developed a soil classification system that is incorporated in their language and culture. The etymology of their classification system and its logical structure makes it similar and comparable with modern soil classification. The etymology of the Xicrin's language is based on the junction of radicals to form words for different soil names. The name of the soil is formed by the main noun radical "puka", to which adjectives referring to soil morphological attributes are added. Modern classification systems are also based on similar morphological variables, and analytical support for defining boundaries of chemical or physical soil attributes are important only in lower hierarchical levels. Soil scientists have developed a soil classification system that is sensitive for the restrictions and potentialities the soil will show for modern agriculture. The Xicrins classify soils for what is important for their life style, i.e. a harmonic and friendly life with the resources they gain from the forest.

Key words: Xicrin do Cateté, Amazon, Brazil, indigenous knowledge

\section{APRENDENDO A CLASSIFICAR SOLOS COM OS ÍNDIOS KAYAPÓ}

RESUMO: A reserva indígena Kayapó-Xicrin do Cateté esta localizada na floresta amazônica no estado do Pará (Brasil). Os Xicrins desenvolveram uma classificação de solo que esta incorporada ao seu idioma e cultura. A etimologia da classificação dos solos e a sua estrutura lógica são similares com os sistemas modernos de classificação de solos. A etimologia do idioma Xicrin é baseada na união de radicais para formar as palavras e a mesma é utilizada para formar os diferentes nomes dos solos. O nome do solo é formado pelo radical principal "puka" ao qual são adicionados adjetivos referentes aos atributos morfológicos dos solos. Os sistemas de classificação de solos modernos também são baseados nos mesmos atributos morfológicos, apesar de que apoio analítico é importante para definir os limites entre os atributos químicos e físicos dos solos em níveis hierárquicos mais baixos. Os cientistas de solos têm desenvolvido uma classificação de solos interpretativa para as restrições e potencialidades que o solo tem para a agricultura moderna. Os Xicrins classificam o solo para aquilo que é importante para a vida deles, uma vida harmônica e simbiótica com a natureza.

Palavras-chave: Xicrin do Cateté, Amazônia, Brasil, conhecimento indígena

\section{INTRODUCTION}

History tells us that the first humans reached the American continent around 15,000 years ago, but an ongoing debate in anthropology and archaeology is discussing evidence that shows that the first native Americans could have inhabited the continent as far back as 40 thousand years ago (Nemecek, 2000). If this is so, we can conclude that the American indigenous civilisation is as old as the European civilisation considering that modern man entered Europe coming from Africa around 50 to 60 thousand years ago (Nemecek, 2000). According to these new evidences between 13,000 and 15,000 ybp man occupied practically all the extent from Alaska down to Tierra del Fuego. The large diversity of climatic conditions and natural resources affected the cultural values of the american indigenous populations. Consequently, the indigenous societies in North America developed different habits if compared with the societies in the tropical regions from Central and South America. Despite this diversity, a common cultural fact, especially in the Brazilian indigenous population, is the lack of sense of property and a harmonic relation with nature. These are the most distinguishing characteristics that differentiate the American indigenous cultures from the European civilizations, in which property and natural resources exploitation were essential for development. Oppression and a great anxiety for land domination and transformation are acceptable in one case and make no sense in the other (Pompeu de Toledo, 2000). 
The indigenous Brazilian societies structured their life around the rich biodiversity offered by the Amazonian forests and the favorable climatic conditions that have remained invariable for the last 15,000 years. For getting food and raw materials they improved extractivism, hunting and fishing. Some societies developed an incipient agriculture domesticating some specific forest plants. The subsistence of these societies depended on the conservation of their natural resources and a harmonic relationship with nature. Destruction of the forest would threaten their food, medicine and raw materials sources. These inherited cultural marks reflect the way humans relate with natural resources and consequently the way they classify them. Classification is usually an attempt to group things according to their functionality.

\section{Context}

During the last 20 or 30 years the interest of studying indigenous cultures and their classification systems has grown. A branch of anthropology and biology, called ethno-biology, specializes in the study of indigenous biological classification systems (plants, animals, etc.). Soils, as part of nature, also have their own indigenous classification system. Although less studied if compared with plant and animal classifications, an important number of reports have concentrated on specific soil classification systems developed by local indigenous cultures in different sites of Central and South America (Posey, 1984; Sandor \& Furbee, 1990; Stacishin de Queiroz \& Norton, 1992).

The indigenous group Kayapó Xicrin do Cateté (Jê linguistic family) is settled in Pará (Brazil), between the latitudes $6^{\circ} 00^{\prime}$ and $6^{\circ} 30^{\prime} \mathrm{S}$ and longitudes $50^{\circ} 30^{\prime}$ and $51^{\circ} 00^{\prime} \mathrm{W}$. The Xicrin Indians have an excellent knowledge of their environment and have developed a classification system for plants and animals (Giannini, 1991). As a result of a field survey within the Xicrins reserve to evaluate its potential for agroforestry we casually discovered that the Xicrins also developed a soil classification system that has not been reported comprehensively before.

\section{RESULTS AND DISCUSSION}

\section{The Kayapó-Xicrin do Cateté classification system}

When classifying natural objects the occidental society divides nature into animals (including Man), plants and minerals. The Xicrins divide nature into categories that have different divisions and contrasts with the western scientific knowledge. These categories are related to the domains of the Xicrin's universe: soil (puka), sky (koikwa) and water (ngô) (Giannini, 1991).

In the Xicrin language, the etymology of the words is based on the junction of radicals that have specific meanings. The general structure the Xicrins use to build words is the same they use to name soils. When classifying soils, supra-generic and generic categories of radicals are grouped. Several radicals (generic categories) that refer to the different soil attributes (adjectives), are added to the main noun radical "puka" (supra-generic category). The name of the soil can be simple, formed by one adjective, or compound, formed by two or more adjectives, creating different generic categories of soils (Figure 1).

Among the most used soil attributes, soil texture (soil particle distribution) and color appear in most indigenous soil classification systems. For example, the indigenous group of the Acarau valley (Ceará, Brazil) (Stacishin de Queiroz \& Norton, 1992) developed a soil classification system that is based on soil texture, color, structure and depth; the Calva indians in Peru use soil texture and other properties that influence soil management (Sandor \& Furbee, 1990); the Kuikuro indians from Alto Xingú (Pará, Brazil) (Ribeiro, 1992) classify the soil using soil texture and moisture.

The Xicrins, comparable to other soil classification systems, also use easily observable soil attributes such as soil color, texture, stoniness and soil moisture. The attribute soil color is divided into four: white $(\boldsymbol{a k a})$, red (kamrek), yellow (ngrã) and black (tuk). The adjective $\boldsymbol{k r} \boldsymbol{u}$ describes the presence of stones in the soil profile. The soil moisture is described in two ways: a) when the profile is dry and hard, tudji, and b) when the profile is wet, $\boldsymbol{n g} \boldsymbol{u}$, which in the Xicrin language refers more appropriately to the usual clayey plasticity, stickiness and moisture (Figure 1).

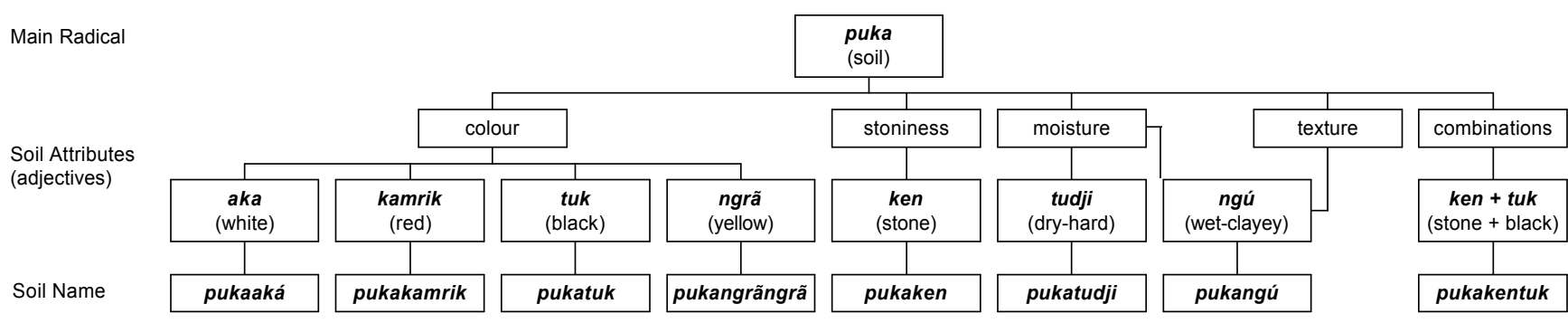

Figure 1 - Soil name formation used in the Xicrin soil classification system starting with the main radical puka.

Sci. Agric. (Piracicaba, Braz.), v.62, n.6, p.604-606, Nov./Dec. 2005 
The Kayapó-Xicrin soil classifcation system versus modern soil classifcation systems

The modern soil classification systems, all developed based on the pioneer work of the Russian scientist Dokuchaiev (first published in 1883 (Glinka, 1914)), and the Xicrin classification system are similar in etymology and logical structure. The main soil attributes considered by the Xicrins are based on the same morphological variables as the modern soil classification systems, named morphological because of the fact that they can be observed using human senses. In modern soil classification systems, analytical support is used for defining boundaries of chemical or physical soil attributes and important to separate soils in lower hierarchical levels. This leads to considerable differences between the soil classification systems developed by the Xicrins and the modern soil scientists.

Soil scientists have developed a soil classification system that is sensitive for the restrictions and potentialities the soil will show for modern agriculture. Notwithstanding the great differences in the degree of technological sophistication of both cultures, the system used by the Xicrins internalizes the necessary and sufficient information for their relation with land and nature, which sustained their existence until before contact with Europeans. Probably a better understanding of the indigenous soil classification systems is a first step for a scientific approach to classify tropical soils as a pure natural resource. A functional analysis, i.e. what each soil classification cat- egory means for Xicrins' life and how these categories relate with plants, animals and water, may be the next step towards a more comprehensive understanding of the indigenous soil classification system. This is a lesson the modern soil scientist has to learn from the Xicrins and from which we may benefit with a tropical soil classification system that has nature and not agriculture as target (Niemeijer, 1995).

\section{REFERENCES}

GIANNINI, I.V. A ave resgatada: "A impossibilidade da leveza do ser". São Paulo:USP/FFLCH, 1991. 205p. (Dissertação - Mestrado).

GLINKA, K.D. "Dokutschajeff Kartographie der russischen Böden" Die Typen der Bodenbildung, ihre Klassifikation und geographische Verbreitung. Gebrüder Borntraeger, v.1, p.1-9, 1914.

NEMECEK, S. Who were the first Americans? Scientific American, v.283, p.80-87, 2000.

NIEMEIJER, D. Indigenous soil classifications: complications and considerations. IK Monitor, v.3, p.20-25, 1995.

POMPEU DE TOLEDO, R. O exemplo dos bons selvagens. Veja, p.6469, 2000. Ed. Especial

POSEY, D.A. Os Kayapó e a natureza. Ciência Hoje, v.2, p.35-41, 1984. RIBEIRO, B. Ao vencedor, as batatas. Ciência Hoje, v.15, p.111-114, 1992.

SANDOR, J.A.; FURBEE, L. Indigenous knowledge of soils in the Colca valley, Peru. In: ANNUAL MEETING, San Antonio, 1990. Agronomy abstracts. Madison: ASA, 1990.

STACISHIN DE QUEIROZ, J.; NORTON, B.E. An assessment of an indigenous soil classification used in the Caatinga region of Ceará state, Northeast Brazil. Agricultural Systems, v.39, p.289-305, 1992.

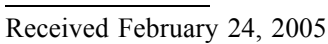

Accepted October 07, 2005 